УДК 130.2

\title{
А.В. Емельянов
}

\section{СИМВОЛИЧЕСКИЙ УНИВЕРСУМ СОВРЕМЕННОГО МИРА}

В статье рассматриваются примеры символических, виртуальных артефактов как части социальной реальности современного мира. Анализируется влияние символической реальности на человека, трансформации форм восприятия, отражения мира. Символический мир, мир симулякров исследуется в контексте инструмента влияния на различные сферы жизни общества. Приводятся примеры символических структур, задействованных в различных формах социальной жизни, вовлеченности символических форм отражения мира в механизмы восприятия, принятия решений. Рассматривается взаимосвязь условно реального и условно виртуального миров, их взаимопереплетения, взаимообратимости. Показана взаимосвязь символа и симулякра как более современной и более сложной формы, характеризующей состояние текущей социальной реальности, приведены примеры феноменов симуляционной реальности в постсовременных обществах. Анализируются этические стороны расширения символических пространств человека, причины их появления и развития, последствия существования для человеческой цивилизации.

Ключевые слова: социальная реальность, виртуальная реальность, социальные сети, дискурс, символ, симулякр.

DOI: $10.35634 / 2412-9550-2021-31-2-155-159$

Современный мир все больше движется в сторону расширения и разнообразия символических пространств. Под последними могут пониматься довольно широкие спектры явлений: это и пространства интернета (в широком смысле этого понятия), и развитие разнообразных и порой неожиданных видов искусств (для анализа последнего достаточно привести тот факт, что большая часть культурных жанров - кино, музыка, театр, фотография - получили свое интенсивное развитие лишь недавно - с началом XX века), и многочисленные формы трансформации человека и человеческой телесности, появление разнообразных роботов, попытки изменения человеческой природы с точки зрения ее внешних форм, здоровья и т. п. Все эти тенденции зародились отнюдь не в современной культуре последних столетий, однако именно в этот период получили свое интенсивное воплощение. Всё это позволяет родиться размышлениям об изменении человеческой сущности (или, во всяком случае, о ее существенных трансформациях), о переходе человечества к новым рубежам смыслов и целей, об изменении в когнитивных структурах познания и понимания мира. На наш взгляд, все это целесообразно рассмотреть и охватить через категорию символического универсума современного мира, под углом зрения символизма и именно расширения символических пространств рассмотреть тенденции развития современной цивилизации.

Идея о символической природе человеческой сущности в целом отнюдь не является новой. Культура в широком смысле этого слова всегда строилась на символической основе, знаки и символы являются способом интерпретации, понимания культуры. Некий параллельный, символический мир представляет собой вариант бытия человека как существа не только и не столько природного, социального. Однако именно в последние десятилетия, столетия (точные временные рамки здесь устанавливаются лишь приблизительно, совпадая с интенсификацией развития человеческой цивилизации в целом) символический мир стал расширяться, множиться и, по словам Ж. Бодрийяра, не столько отражать, изображать, сколько заменять собой реальность. Здесь возникает потребность для анализа последствий этого явления, возможных мировоззренческих, познавательных, этических смыслов, возникающих в связи с тем, что природа человека как бы двоится, виртуализируется. Теряет ли в этом случае человек свою сущность или, наоборот, обретает ее заново, отдаляется ли он от природы или находит новые грани ее применения и использования.

Все это, выражаясь языком Г. Гегеля, можно рассматривать как варианты самопознания, воплощения человеческой природы, движения, которое никогда не останавливалось и обретает в текущей ситуации новые, неожиданные стороны.

Символический универсум - довольно широкое понятие, трактуемое автором данной статьи не только и не столько в культурологическом, эстетическом смысле. Скорее, речь в большей степени целесообразно вести о широкой повседневности, том фоне, который задают средства массовой информации, реклама, интернет-месседжи, а также обо всем том, что в широком смысле этого слова 
можно было бы назвать словом «идеология». Последняя отнюдь не исчезает, но становится все более разнообразной, изощренной и порой с трудом поддающейся анализу, обобщению, что в свою очередь порой порождает серьезные трудности в анализе. Является ли современное общество постсовременным, постиндустриальным - вопросы открытые, во всяком случае требующие регулярно пересматривать их определения и формулировки.

Рассмотрим некоторые символические атрибуты, столь характерно распространенные в повседневности, СМИ и порой не вызывающие никаких особых дополнительных вопросов.

1. «Брящанье оружием». Милитаризация современного мира подчиняется сложной игре реального и символического, во всяком случае, с изобретением все более и более сложных, смертоносных видов вооружения сфера оружия, войны переходит во все более и более виртуальные, символические формы. Последнее является как абсолютно оправданным, вынужденным, так и одновременно абсурдным, искусственным. Как правило, ежедневно с экранов телевизора, рекламных щитов, выставок, инсталляций демонстрируются различные виды вооружений, ведется непрерывный милитаристический дискурс, сопрягаемый со стратегиями патриотизма, державности, маскулинности и др. До недавнего времени этот дискурс действительно был виртуальным, символическим, воспринимаемым как нечто отдаленное, пережитое, однако в связи событиями в Украине, регулярными сообщениями об актах терроризма он имеет свойство переходить из виртуальной фазы в реальную, когда за символом открывается и оказывается воплощенной та страшная реальность, на которую данный символ указывает. Символизм оружия, милитаризации является одновременно как вынужденной, так и необходимой мерой, демонстрирующей и раскрывающей некоторые сущностные особенности человеческой природы.

2. Социальные сети. Экспансия интернета на все сферы жизни человека породила в том числе и такой своеобразный феномен, как социальные сети. Люди стали активно общаться виртуально, возникла некая параллельная вселенная, где у каждого человека появился виртуальный двойник - фотография, аккаунт, видеоряд, но, кроме всего прочего, совокупность сопутствующих атрибутов - круг фото-, видеозаписей, музыки, статусов, комментариев, постов и пр. Поначалу во второй половине 2000-х гг. это вызывало неподдельный интерес, затем, по мнению многих аналитиков, происходило и происходит постепенное уменьшение интереса к этому. В то же время реальные тенденции в данной сфере постоянно меняются, и отследить текущее положение дел можно лишь приблизительно.

Социальные сети породили ряд феноменов, своеобразно иллюстрирующих некие трансформации привычных культурных механизмов. Так, одним из довольно известных клипов рэпера Егора Крида стала песня «Любовь в Сети» - некий памфлет, содержащий ненормативную лексику, но тем не менее указывающий на своеобразные культурные формы. Люди - участники сетевого общения, социальных сетей, стали признаваться в любви на основе статусов, испытывать виртуальные, но не реальные чувства; человек как бы превращался в свой символ, состоящий из фотографий, записей, постов, статусов. Возникла (и никуда не исчезает) своеобразная мифология, когда о человеке судят не по реальному его состоянию, а по профилю в социальной сети, могут реагировать на его чувства, настроения, предпочтения и т. д. При этом возникает ситуация даже посложнее, чем «копия копий»того, что Ж. Бодрийяр вкладывал в понятия «симулякр»: и авторы, и реципиенты могут создавать мифологию самих себя, верить в нее и следовать либо же, наоборот, полностью не соответствовать.

3. Виртуальный мир компьютерной реальности. Современный человек живет в неотъемлемом мире виртуальных технологий, замещающих, а порой и заменяющих мир реальный. Было бы не совсем корректно сводить виртуальную реальность целиком к символическим формам, т. е. понимать ее только в контексте теории символов, однако многочисленные формы виртуальной реальности могут трактоваться именно как символическая, знаковая реальность. Мир компьютерных технологий настолько многомерен и так стремительно изменяется, что порой его рефлексия, т. е. осмысление того, что стоит за всем этим и как в результате меняется природа, культура, не успевает за появляющимися новинками. Здесь можно привести в пример и робототехнику, и многочисленные варианты 3D-, 4D5D- и так далее реальностей, видеотехнологии, позволяющие моделировать с поразительной точностью реальных людей, объекты, ситуации (все это было хорошо предсказано и описано десятилетия назад, скажем, в «Магеллановом облаке» С. Лема и в других произведениях научной фантастики); феномен фейковых новостей и др. Символическая виртуальная реальность такова, что стирает грани между собственно реальностью и ее имитацией.

Символический универсум в той или иной степени всегда сопровождал человека. Но если исторически данная сфера тяготела к области трансцендентного, религиозных символов и смыслов, то в со- 
временную эпоху под трансцендентным может пониматься мир невозможного, фантазийного, придуманного возможностями технологической эпохи. Символизм как форма зрелищного обращается к недоступным областям: это могут быть символы бога, духов либо же символы и атрибуты власти - той в широком смысле слова сферы, которая довлеет, доминирует над человеком, оставаясь при этом недоступной, неизменяемой. Власть в современную эпоху (при том, что традиционные ее смыслы никуда не исчезают) - это власть образа, фантазии, выдуманного мира, создаваемого всеми возможными техническими устройствами. По словам Е.Г. Прилуковой, «властвование проступает как предъявление образов: кто выделяет и наделяет значением события, тот овладевает ими и другими» [12. С. 63].

Исследуя символическую реальность современного мира, довольно часто прибегают к категории симулякра. Существует довольно большое количество исследований, так или иначе интерпретирующих данное понятие (см., напр.: $[1 ; 7 ; 11 ; 12])$. Концептуальное отражение проблема симуляции реальности приобрела в постмодернистских работах Ж. Делеза, Ж. Бодрийяра [2] и других авторов, наполнившись многочисленными примерами форм и видов симулякров, многочисленными вариациями интерпретации данного термина. Представляется, однако, что способ рационального освещения данной темы должен следовать в русле разделения оппозиций реального и мнимого, этического и безнравственного, истинного и ложного и т. д. Так, можно объявлять всю реальность иллюзией (в духе знаменитого афоризма «Жизнь - это сон»), все искусство - фантазмом или все новости - продуктом компиляции указаний власти и технического монтажа журналистского материала, однако такой подход не дает и не придает нового знания. Рассматривая символические пространства, целесообразно удерживать в поле рефлексии и категорию «не-символического», того, что можно называть реальным, подлинным, природным, в многочисленном спектре преломлений данных понятий в различных дискурсах.

К примеру, при всем развитии медицинских технологий протезирование пока что не способно заменять реальные органы в полноценном смысле альтернативы созданному природой. Роботы, какими бы совершенными они ни были, остаются в той или иной степени игрушками, формой творчества для развлечения. Компьютерная, симуляционная реальность позволяет решать многие задачи, но, по словам Т.В. Черниговской, компьютерные технологии могут не совпадать с «человекомерностью» и в отдельных случаях могут приводить к трагическим результатам, как, например, полная передача управления транспортным средством программам без участия человека [15]. «Человекомерность» можно применять и к творчеству, и к научным рассуждениям: не является секретом, что современные технологии существенно облегчили манипулирование информацией, однако последнее приводит к ее многочисленному мультиплицированию, что не способствует, а, скорее, препятствует появлению оригинальных произведений (художественных, научных, культурных). Возникает своего рода специфическая утомленность, ощущение бессмысленности от очередного кинематографического блокбастера с огромным количеством спецэффектов либо же от мультиплицирования схожих сюжетов в массовых книгах, сериалах, фотографиях, научной информации, при которых мерилом оказывается некий стандарт - символ, в отношении которого строится произведение. Символизм современного мира тесно пересекается с информационностью, теми технологическими реалиями, по пути которых пошло человечество и которые заново позволяют определять и переопределять человеческую природу, потенциальные возможности.

В статье В.А. Емелина [7] приводятся яркие примеры тех опасностей, мифологических вывертов, которые способна творить симулякризованная реальность. Так, группа Pussy Riot была мало кому известным андеграундным коллективом, решила провокационно станцевать в храме, выложила ролик, и из этого рядового, в сущности, события вылились совершенно непредсказуемые последствия: уголовные преследования, клерикализация общества, изменения в законодательстве, тектонические изменения в сознании и дискурсе всего общества. Рядовая встреча премьера Д. Медведева с жителями регионов, к примеру Крыма, и произнесенная им в контексте фраза «Денег нет, но вы держитесь», выхваченная журналистами, превратилась в один из массовых мемов, отразившись в тысячах комментариев и их интерпретаций, стала своего рода символом-слоганом отношений власти и общества. Военные действия, т. е. массовое уничтожение людей, в постмодернистскую эпоху превращаются в симулякрысимволы, транслируемые с медиа-экранов и порой перемешиваемые с их компьютерными двойниками, маскируются словесными языковыми играми наподобие «миротворческой акции», «антитеррористической операции», «миссии по восстановлению доверия» и т. п. Как замечается автором, «симулякры не безобидны, особенно когда они из виртуальности приглашают в действительность» [7. С. 93]. 
В то же время нарастание символических, симулякризованных форм выступает как вынужденная, необходимая вещь, как определенная форма тотальности, по которой движется человеческая цивилизация. Здесь оказывается переплетенным множество факторов, взаимно обуславливающих друг друга: научно-технический прогресс, нарастание свободы, гуманизация человечества, рост народонаселения, перемещение и перемешивание (виртуальное и реальное) самых разных слоев населения, представителей разных социальных стратегий. Символический симулятор войны или автокатастрофы - необходимость и вынужденность замещения их реальных аналогов, виртуальное символическое общение в социальных сетях дает замену реальному взаимодействию в атомизированном, индивидуализированном мире социальных пространств, научно-технические и компьютерные технологии создают разнообразные формы видимости, замены реальных предметов на виртуальные, касается ли это медицины, еды, обучения, быта и т. д. Наконец, улучшение качества жизни, увеличение численности населения и расширение их участия в разнообразных культурных формах приводят к расширению и разнообразию символической стороны человеческого бытия. Как сказано об этом у Э. Кассиpepa, человек «настолько погружен в лингвистические формы, художественные образы, мифические символы или религиозные ритуалы, что не может ничего видеть и знать без вмешательства этого искусственного посредника» [4. С. 471].

Таким образом, современный человек сталкивается с существенным усложнением социальной реальности, в которой символический мир присутствует в качестве важнейшего компонента. Виртуальная реальность коррелятивна технологическому развитию, отчасти сфере желаний, устремлений, тем формам, которые вызывают интерес, но также и потребности, возможности. Центральной проблемой здесь являются в той или иной степени этические последствия, возможен разговор о «дегуманизации человека» либо же об иных формах «гуманизации», т. е. облика, ценностей людей уже в новой реальности. Данный вопрос является открытым для анализа.

\section{СПИСОК ЛИТЕРАТУРЫ}

1. Абрамова В.А. Виртуальная реальность как пространство симулякров // Краснодар: Историческая и социально-образовательная мысль, 2017. Т. 9, № 1, ч. 1. С. 99-103.

2. Армер Е.В. Место социальных коммуникаций в картинах социальной реальности // Научный потенциал, 2013. № 3 (12). С. 9-15.

3. Бодрийяр Ж.Символический обмен и смерть. М.: Добросвет, 2000. 387 с.

4. Гегель Г. Энциклопедия философских наук. Т. 3. Философия духа. М.: Мысль, 1977. 471 с.

5. Губман Б.В. В универсуме символического мира культуры // Новое в психолого-педагогических исследованиях. 2013. № 4 (32). С. 224-228.

6. Делез Ж. Различие и повторение. СПб.: Петрополис, 1998. 384 с.

7. Емелин В.А. Симулякры и технологии виртуализации в информационном обществе // Национальный психологический журнал. 2016. № 3 (23). С. 86-97.

8. Кассирер Э. Избранное. Опыт о человеке. М.: Гардарика, 1998. 784 с.

9. Кастельс М. Галактика Интернет: Размышления об Интернете, бизнесе и обществе. М.: У-Фактория, 2004. $328 \mathrm{c}$.

10. Милецкий В.П. Конфликт поколений в современном обществе: симулякры общества постмодерна или прозаическая повседневность // Информация - Коммуникация - Общество. 2013. С. 117-120.

11. Новикова О.Н. Виртуальный игровой мир как симулякр жизни // Гуманитарный вектор. 2017. Т. 12, № 3. C. $23-29$.

12. Прилукова Е.Г. Власть симулякров: социально-философский аспект // Экономика и политика. 2016. № 2 (8). C. 61-64.

13. Сироткин В.Б. Укрепление доверия в обществе: сопротивление распространению симулякров // Экономическое возрождение России. 2017. № 1 (51). С. 96-109.

14. Тетиор А.Н. Мир с позиций философии множественности. М.: Изд. дом «Академия Естествознания», 2017. $622 \mathrm{c}$.

15. Черниговская T. Есть ли место человеку в будущем мире искусственного. URL: https://www.youtube.com/ watch?v=E3sKLmo8ZJs (дата обращения: 22.05.2021). 
Емельянов Александр Владимирович, кандидат философских наук, доцент, доцент кафедры философии и гуманитарных дисциплин Института истории и социологии ФБГОУ ВО «Удмуртский государственный университет» 426034, Россия, г. Ижевск, ул. Университетская, 1 (корп. 6)

E-mail: avemfurm@yandex.ru

\section{A.V. Emelyanov \\ SYMBOLIC UNIVERSE OF THE MODERN WORLD}

DOI: 10.35634/2412-9550-2021-31-2-155-159

The article deals with examples of symbolic, virtual artifacts as part of the social reality of the modern world. The author analyzes the influence of symbolic reality on a person, the transformation of forms of perception, reflection of the world. The symbolic world, the world of simulacra is considered as an instrument of influence on various spheres of society. Examples of symbolic structures involved in various forms of social life, the involvement of symbolic forms of reflection of the world in the mechanisms of perception, decision-making are given. We consider the relationship between the conditionally real and conditional virtual worlds, their interweaving, reciprocity. The article shows the relationship between the symbol and the simulacrum as a more modern and more complex form that characterizes the state of current social reality, various phenomena of post-modern types of societies, and their historical variability. The ethical aspects of the expansion of symbolic human spaces, the reasons for their appearance and development, and the consequences of their existence for human civilization are considered.

Keywords: social reality, virtual reality, social nets, discourse, symbol, simulacrum.

Received 22.05.2021

Emelyanov A.V., Candidate of Philosophy, Associate Professor at Department of Philosophy and Humanities of Institute of History and Sociology

Udmurt State University

Universitetskaya st., 1/6, Izhevsk, Russia, 426034

E-mail: avemfurm@yandex.ru 